\title{
NEW TRADE AND ECONOMIC REGIONALISM: A SPACE OF OPPORTUNITIES IN GREATER EURASIA
}

\author{
Mark Entin* \\ Dmitriy Galushko** \\ Vladimir Kovalev ${ }^{* * *}$
}

\begin{abstract}
The article is devoted to the issues of trade and economic integration in the Greater Eurasia region. The trends of regionalization in the Asia-Pacific region based on multilateral trade deals are studied. The analysis of the Regional Comprehensive Economic Partnership Agreement, the prerequisites for its conclusion, and the effects of implementation has been carried out. These issues were considered in conjunction with the implementation of the Comprehensive and Progressive Agreement for Trans-Pacific Partnership, including considering the current prerequisites for its expansion. The authors investigate the issues of conjugation of the EAEU and integration processes in the Asia-Pacific region within the framework of the idea of the Greater Eurasian Partnership. Specific proposals for the organization of work, based on the mechanisms for implementing the EAEU's international legal personality, have been formulated. An overview of the possible results of the conclusion of the Agreement in Greater Eurasia in the economic and geopolitical context is presented.

KEYWORDS: Regional Comprehensive Economic Partnership, Comprehensive and Progressive Trans-Pacific Partnership, Eurasian Economic Union, integration, trade and economic cooperation, international legal personality, Great Eurasian Partnership.
\end{abstract}

\footnotetext{
* Mark Entin, MGIMO University, Moscow, Russia; entinmark@gmail.com.

** Dmitriy Galushko, Financial University under the Government of the Russian Federation (Financial University), Moscow, Russia; galushkodv@gmail.com.

****Vladimir Kovalev, Eurasian Economic Commission, Moscow, Russia; v.kovalev@eecommission.org.
} 


\section{INTRODUCTION}

We are witnessing fundamental changes in the architecture of world integration processes. The current stage of their development is characterized by the fragmentation of governance models and the regrouping of forces within the framework of multilateral trade agreements. Since the 2010s, against the background of the weakening of the role of the World Trade Organization and the strengthening of China's position in the global economy, the activity on the formation of regional trade and economic alliances in the Asia-Pacific region (APR) has intensified ${ }^{1}$.

This trend is mediated by specific geo-economic prerequisites. Back in 2011, Singaporean economist D. Quah proposed his model for measuring the point of attraction of the world economy. ${ }^{2}$ The annual GDP of countries according to the World Bank is multiplied by the coordinates of their geographic center, and the resulting weighted average is plotted on the map. As a result, there is a clear tendency for economic activity to move eastward ${ }^{3}$.

The Asia-Pacific region is a complex and heterogeneous macroregion in terms of the level of economic development. The coronavirus pandemic was one of the first to hit the region. However, in such conditions, it was here that the most positive economic results were demonstrated ${ }^{4}$. The growth of the region's aggregate GDP at the end of 2020 amounted to $1.3 \%$, while China's GDP grew by $2.3 \% .^{5}$ For comparison, the US GDP in 2020 decreased by $3.6 \%$, the EU - by $6.2 \% .^{6}$ According to the latest forecasts, the GDP of the Asia-Pacific region in 2021 will grow by a significant $7.5 \%^{7}$ (this is higher than the projected

1 Kawai, M., Wignaraja, G.: Asian FTAs: Trends, Prospects, and Challenges, Asian Development Bank Economics Working Paper Series, 2010, 226, p. 1. URL: http://dx.doi.org/10.2139/ ssrn.1721911, accessed on 23/10/2021.

2 Quah, D.: The Global Economy's Shifting Centre of Gravity, Global Policy, 2011, 2(1), p. 3-9.

3 See e.g.: Smith, H., Day, G., Thomas, B., Yeaman, L.: The changing pattern of East Asia's growth, Economic Roundup, The Treasury, Australian Government, 2005, 1, p. 45-67.

4 Baklanov, P. Y., Romanov, M. T.: Transboundary regions of East Asia: geographical and political preconditions and limitations to long-term development, GEOGRAPHY, ENVIRONMENT, SUSTAINABILITY, 2020, 13(1), pp. 57-63. https://doi.org/10.24057/2071-9388-2019-96.

5 World Bank East Asia and Pacific Economic Update, October 2021. URL: https://openknowledge.worldbank.org/bitstream/handle/10986/36295/9781464817991.pdf?sequence= 2\&isAllowed, accessed on 23/10/2021.

6 See further on the EU post-pandemic development: Entin, M., Galushko, D. Resilience of the European Union as a determinant of its post-pandemic development (2021) Eastern Journal of European Studies, 12, p. 212-230. doi: 10.47743/EJES-2021-SI10

7 World Bank East Asia and Pacific Economic Update, October 2021. URL: https://openknowledge.worldbank.org/bitstream/handle/10986/36295/9781464817991.pdf?sequence= 2\&isAllowed=, accessed on 23/10/2021. 
growth of world GDP, which is expected to be $5.6 \%{ }^{8}$ ). It is not surprising that the most significant events in the field of trade and economic integration are now taking place here.

The most important multilateral format in the APR for a long time has been the Association of Southeast Asian Nations (ASEAN), formed in 1967. It is around the core of ASEAN that the further development of integration processes in the region is taking place ${ }^{9}$. Despite COVID-19, negotiations were completed in 2020 on the creation of the largest free-trade zone in the world - the Regional Comprehensive Economic Partnership (RCEP), which united 10 ASEAN countries, as well as Australia, China, New Zealand, South Korea, and Japan. Another center of regionalization, which has a high potential for influencing the international economic structure, is the Comprehensive and Progressive Agreement for Trans-Pacific Partnership (CPTPP), reformed after the withdrawal of the United States.

Significant interest in closer cooperation with regional structures and individual countries in the Asia-Pacific region is shown by both the European Union and the Great Britain that left it, having radically diversified its foreign trade strate$\mathrm{gy}^{10}$. It should also be borne in mind that, in parallel with economic integration in the region, political and security cooperation initiated by the United States is also gaining momentum (for example, AUKUS, QUAD, Five Eyes, Blue Dot Network), designed to curb the growing influence of new centers of power.

The post-image world can already be unambiguously called the world of new regionalism. And this is only the beginning of a global restructuring. In such conditions, the building of a strategic partnership between the leading players of Greater Eurasia, where one of the most important roles belongs to Russia and its allies in the Eurasian Economic Union (EAEU), is of particular relevance, and the present paper aims at answering questions on cooperation and positioning of EAEU within these modern circumstances. The creation of seamless regulation, increased transparency and balance of trade, and economic interaction meets the interests of all parties.

\footnotetext{
8 Global Economic Prospects. June 2021. URL: https://openknowledge.worldbank.org/bitstream/handle/10986/35647/9781464816659.pdf, accessed on 23/10/2021.

9 Yates, R.: Understanding ASEAN's role in Asia-Pacific order. London, Palgrave Macmillan, 2019. (Critical Studies of the Asia-Pacific). https://doi.org/10.1007/978-3-030-12899-9

10 See e.g.: Dowd, K.: A Trade Policy for a Brexited Britain, Institute of Economic Affairs Discussion Paper, 2017, 85, 2017. URL: https://ssrn.com/abstract=3853711, accessed on 23/10/2021.
} 


\section{RCEP AND CPTPP: WHAT IS IT, WHAT IS THE DIFFERENCE, AND WHAT ARE THE PROSPECTS?}

\subsection{REGIONAL COMPREHENSIVE ECONOMIC PARTNERSHIP AGREEMENT: FEATURES AND IMPACTS.}

The signing of the Regional Comprehensive Economic Partnership Agreement took place on 15 November 2020 during the 37th ASEAN Summit. ${ }^{11}$ This was preceded by 8 years and 31 rounds of negotiations. Not without losses: at the final stage, India left the project, stating that «its conditions do not meet the interests of all residents of the country». ${ }^{12}$ This is an unambiguous minus; with the participation of India, the RCEP would become an even more powerful trade and economic grouping. But even without that, the numbers speak for themselves. The total GDP of the parties to the Agreement is about 26 trillion US dollars (about 30\% of world GDP), their share in world trade is similar, and the total market covers more than 2.2 billion people. ${ }^{13}$ All existing integration entities and trade unions, including the EU, USMCA (an updated version of NAFTA), MERCOSUR, as well as another regional giant, CPTPP, remain far behind.

The RCEP's great potential is associated with a fundamentally new format for the consolidation of key players. For the first time, the three largest economies of Asia - China (No. 2 in the world), Japan (No. 3 in the world), and South Korea (No. 12 in the world) united within the framework of a single free trade area. Australia and New Zealand were added to them (ASEAN +2 format). RCEP harmonizes previously concluded bilateral trade deals between ASEAN countries and its five other participants.

The agreement clearly reflects the trade paradigm that is emerging in the APR. Its main goal is to create conditions for building up intraregional trade and industrial cooperation ${ }^{14}$. For clarity, we note that by the end of 2020, ASEAN became China's largest trading partner, for the first time ahead of the EU and the

\footnotetext{
11 RCEP free trade deal signed among 15 participating countries. URL: http://english.www. gov.cn/news/internationalexchanges/202011/15/content_WS5fb0cf8dc6d0f7257693fd7b.html, accessed on 23/10/2021.

12 Asia trade pact doesn't reflect India's interests, decided not to join: PM Modi. URL: https:// www.reuters.com/article/us-asean-summit-india/india-decided-not-to-join-rcep-trade-dealpm-modi-idUKKBN1XE1EL?edition-redirect=uk, accessed on 23/10/2021.

13 World Bank Data. URL: https://data.worldbank.org/, accessed on 23/10/2021.

14 Flach, L., Hildenbrand, H., Teti, F.: The Regional Comprehensive Economic Partnership Agreement and Its Expected Effects on World Trade, Intereconomics, 2021, 56(2), p. 92-98.
} 
United States, and ASEAN's share in all of China's foreign trade approached $15 \%{ }^{15}$. There is something to think about.

The RCEP agreement will enter into force 60 days after ratification by six ASEAN member states and three out of five other signatories. China, which was one of the first to ratify the document, announced back in March 2021 that it expects it to enter into force on 1 January $2022 .{ }^{16}$

The brief analysis of RCEP let us define its following main features and possible results of its implementation:

- of greatest importance is the unification of the rules for determining the country of origin of goods. This is a key factor in creating new value chains in the region;

- within 20 years, tariffs will be reduced by approximately $92 \%$ of all turned over goods. Most RCEP participants already have valid trade agreements with each other. Therefore, liberalization will mainly affect the China-Japan pairs, as well as Japan-Korea, which previously did not have such agreements among themselves, but at the same time are significant partners;

- RCEP covers $65 \%$ of the types of services according to the UN classifier. It will be impossible to roll back to the previous level of protection of this or that sector after the adoption of measures to liberalize it;

- harmonization and mutual recognition of the conformity of SPS measures and technical standards will ensure market transparency. In particular, the importing party will have to recognize the requirements of the exporter as equivalent if they meet the same goals and objectives as the measures of the importer;

- special attention is paid to the simplification of customs procedures, investment regime, protection of intellectual property, and e-commerce (transition to paperless interaction with the customs administration and widespread use of electronic digital signatures). ${ }^{17}$

15 Overview of China-ASEAN Economic and Trade Relations, Opportunities and Challenges. Remarks by H.E. Ambassador Huang Xilian, Chinese Ambassador to the Philippines. URL: https://www.fmprc.gov.cn/mfa_eng/wjb_663304/zwjg_665342/zwbd_665378/t1907333.shtml, accessed on 23/10/2021.

16 What is the Ratification Status of the RCEP Agreement and When Will it Come into Effect? URL: https://www.china-briefing.com/news/ratification-status-rcep-expected-timelinechina-thailand-already-ratified/, accessed on 23/10/2021.

17 Regional Comprehensive Economic Partnership Agreement. URL: https://rcepsec.org/ legal-text, accessed on 23/10/2021. 
In purely economic terms, the RCEP will have a major impact on the development of the bloc itself. Strengthening of regional specialization of Asian manufacturers, relocation of industrial production is expected. As a result, the emergence of new jobs and the leveling of people's living standards. Expansion of the range of products and their nature. Since it will become much easier to build value chains, we will increasingly talk about complex high-tech industries, and not just about consumer products. At the same time, this will affect the cost of goods and increase their competitiveness in foreign markets. In short, "Made in RCEP" is a new reality.

RCEP is a classic free trade area, devoid of any elements of a more advanced integration project. There are no requirements for the protection of the environment and labor rights, as well as any regulation of the activities of state-owned enterprises. All this lowers the "entry threshold". The Agreement is open for the accession of other states or individual customs territories 18 months after its entry into force. Without a waiting period, India can join the RCEP. ${ }^{18}$

Even if RCEP does not imply deep integration, its launch puts serious pressure on the United States and the EU, which have not recently made more or less serious progress in implementing their foreign trade agenda. ${ }^{19}$ The EU is fighting Brexit and is unable to ratify already prepared documents such as CETA, EU-MERCOSUR, or the EU-China Comprehensive Agreement on Investments (CAI). Asian countries, on the other hand, are showing a willingness to reach mutually beneficial compromises and unite. The representatives of Brussels diplomacy can only give general comments on the strategic importance of the APR for the European Union and the need to strengthen multilateral economic cooperation, ${ }^{20}$ as well as calculate possible ways to enter the common market through the already concluded free trade agreements with South Korea, Singapore, and Vietnam.

For China, RCEP has a pronounced image value, consolidating its leadership in the process of building trade alliances in the APR. Chinese Foreign Ministry spokesman (aka "Wolf Warrior") Zhao Lijian called the signing of the

\footnotetext{
18 Regional Comprehensive Economic Partnership Agreement. URL: https://rcepsec.org/ legal-text, accessed on 23/10/2021.

19 See, e.g.: Woolcock, S.: The role of the European Union in the international trade and investment order, LSE Research Online Documents on Economics 102821, London School of Economics and Political Science, LSE Library, 2019.

20 The Regional Comprehensive Economic Partnership - what does it mean for the EU? URL: https://eeas.europa.eu/headquarters/headquarters-homepage/88997/regional-comprehensiveeconomic-partnership---what-does-it-mean-eu_en, accessed on 23/10/2021.
} 
Agreement "a milestone in regional economic integration", ${ }^{21}$ and the Chinese media «the victory of multilateralism over unilateralism and free trade over protectionism $»^{22}$. RCEP is interesting not only in itself but also in connection with the equally ambitious CPTPP. According to the forecast of the Asian Development Bank, the combination of the effects of the implementation of RCEP and CPTPP will increase real global income by more than 330 billion US dollars. ${ }^{23}$

\subsection{COMPREHENSIVE AND PROGRESSIVE AGREEMENT FOR TRANS-PACIFIC PARTNERSHIP: FEATURES AND IMPACTS.}

In contrast to the first, CPTPP is more focused on the development of high-level standards, including in areas not covered by RCEP. For example, the Agreement contains rules applicable to labor relations and environmental issues. ${ }^{24}$ An independent arbitration mechanism for resolving trade disputes has been proposed, high standards are applied to the protection of intellectual property. ${ }^{25}$ There is still no China here, at one time the Agreement was conceived by the United States precisely as a counterbalance to the growing power of the PRC. There is no South Korea either, but there is Canada, Mexico, Peru, Chile, and the UK may appear soon. ${ }^{26}$

Today, considerable attention is riveted to the CPTPP, primarily due to the unfolding information hype regarding its expansion. Back in November 2020, China first announced its desire to join CPTPP. On 16 September 2021, an of-

\footnotetext{
${ }_{21}$ China Leans into RCEP Conclusion as Win. URL: https://thediplomat.com/2020/11/chinaleans-into-rcep-conclusion-as-win/, accessed on 23/10/2021.

22 RCEP agreement victory for multilateralism, free trade. URL: http://global.chinadaily. com.cn/a/202011/17/WS5fb33050a31024ad0ba94965.html, accessed on 23/10/2021.

23 Regional Comprehensive Economic Partnership: Overview and Economic Impact. URL: https://www.adb.org/sites/default/files/publication/664096/adb-brief-164-regional-comprehensive-economic-partnership.pdf, accessed on 23/10/2021.

24 Comprehensive and Progressive Agreement for Trans-Pacific Partnership text and resources. URL: https://www.mfat.govt.nz/vn/trade/free-trade-agreements/free-trade-agreements-inforce/comprehensive-and-progressive-agreement-for-trans-pacific-partnership-cptpp/, accessed on $23 / 10 / 2021$.

25 Ibid.

26 Brexit Britain ready to reap 'large benefits' of £9trillion trading bloc. URL: https://www. express.co.uk/news/politics/1499658/Brexit-news-trade-deal-CPTPP-economy-Julian-JessopEU, accessed on 23/10/2021.
} 
ficial application has been already sent. ${ }^{27}$ At first glance, it looks like a kind of geopolitical gambit, a kind of "desire for control" over the region. ${ }^{28}$ Yes, right now it will be very difficult for the PRC to fulfill the high requirements of CPTPP. Recently, however, China has been consistent and has shown amazing negotiability in everything that concerns the advancement of its strategic trade and economic initiatives. All issues were promptly settled both in relation to the investment agreement with the EU and in the framework of multi-stage negotiations on RCEP. The PRC takes an extremely constructive position in promoting "One Belt, One Road". The Chinese officials know-how and want to negotiate. In addition, the requirements for joining CPTPP can become an incentive for domestic transformations, which have already been carried out recently. ${ }^{29}$ In a word, China is persistently "posting" the leadership in the Asia-Pacific region - not in words, but deeds.

Following China, on 23 September Taiwan applied to join the CPTPP. ${ }^{30}$ In addition, Thailand has repeatedly expressed interest to join the trade bloc. ${ }^{31}$ However, more significant in a global context is seen the application for membership in the USPCC from the UK. Today, the United Kingdom seeks to conclude trade deals with almost the whole world at once, which is the latest announcement about the beginning of negotiations with the Cooperation Council of the Arab States of the Gulf (GCC) ${ }^{32}$ or the intention to join USMCA. ${ }^{33}$ The process of joining CPTPP was launched in the summer of 2021, and the negotiations themselves began at the end of September. ${ }^{34}$ Before that, British

27 China Wants to Join the Trade Pact Once Designed to Counter It. URL: https://foreignpolicy. com/2021/09/21/china-cptpp-trade-agreement/, accessed on 23/10/2021.

28 U.S., China Jockey for Position in Pacific with Moves on Security, Trade. URL: https:// www.wsj.com/articles/biden-administration-officials-try-to-soothe-france-over-australia-submarine-deal-11631821352, accessed on 23/10/2021.

29 Don't Count China Out of the CPTPP. URL: https://thediplomat.com/2021/09/dont-countchina-out-of-the-cptpp/, accessed on 23/10/2021.

30 Taiwan Applies to Join Pacific Trade Deal Days After China. URL: https://www.bloomberg. com/news/articles/2021-09-22/taiwan-applies-to-join-pacific-trade-deal-just-days-after-china, accessed on 23/10/2021.

31 Thailand called upon to reassess impact of CPTPP. URL: https://www.bangkokpost.com/ business/2185031/thailand-called-upon-to-reassess-impact-of-cptpp, accessed on 23/10/2021.

32 UK prepares for trade deal with Gulf Cooperation Council. URL: https://www.gov.uk/ government/news/uk-prepares-for-trade-deal-with-gulf-cooperation-council, accessed on 23/10/2021.

33 UK pins hope on joining US-Mexico-Canada trade pact. URL: https://www.ft.com/content/b519921f-8d14-4948-9afa-f2340b0d25db, accessed on 23/10/2021.

34 UK kickstarts talks to join $£ 9$ trillion global trade bloc. URL: https://www.gov.uk/government/news/uk-kickstarts-talks-to-join-9-trillion-global-trade-bloc, accessed on 23/10/2021. 
Foreign Secretary Elizabeth Truss even made a voyage to Mexico in order to enlist the support of an influential party to the Agreement. ${ }^{35}$ And the British government has already calculated the potential benefits. In the case of joining the bloc, exports to CPTPP countries should increase by $65 \%$ by 2030 and reach 37 billion pounds. ${ }^{36}$ Apparently, the negotiations may well be crowned with success, and Great Britain will become the first country in the European region to join the multilateral trade agreement in the APR. In such conditions, it is impossible to waste time. The Eurasian Economic Union, one of the most advanced in terms of integration in the world, should show an interest in the Asia-Pacific region. ${ }^{37}$

\section{TOWARDS A GREATER EURASIAN PARTNERSHIP THROUGH THE UNIFICATION OF THE POTENTIALS OF EAEU AND APR}

The large-scale project of creating a free trade area of the Asia-Pacific Economic Cooperation (APEC) should be implemented taking into account the best practices and experience of the key integration formats of the APR and Eurasia, including the Eurasian Economic Union, in which Russia cooperates with Armenia, Belarus, Kazakhstan, and Kyrgyzstan. EAEU develops dynamically, and it is ready to build relations with all interested countries and associations. It should be noted an idea of creating a Greater Eurasian Partnership. ${ }^{38}$ This approach remains relevant to this day. Russia and the EAEU simply have to become an effective link in Greater Eurasia.

Firstly, today the share of the RCEP member countries accounts for almost a third of the total foreign trade of the EAEU $-30.18 \%$ (while the share of the

35 Liz Truss jets off to seal another Brexit trade deal paving way for £110billion agreement. URL: https://www.express.co.uk/news/politics/1495242/brexit-news-liz-truss-mexico-tradedeal-latest-foreign-secretary-visit, accessed on 23/10/2021.

36 UK Accession to CPTPP: The UK's Strategic Approach. URL: https://assets.publishing. service.gov.uk/government/uploads/system/uploads/attachment_data/file/1027860/dit-cptppuk-accession-strategic-approach.pdf, accessed on 23/10/2021.

37 EAJeS zanjal 2-e mesto posle Evrosojuza po urovnju institucional'noj integracii [The EAEU ranked second after the European Union in terms of institutional integration.] (in Russ.). URL: https://eec.eaeunion.org/news/eaes-zanyal-2-e-mesto-posle-evrosoyuza-po-urovnyu-institutsionalnoj-integratsii, accessed on 23/10/2021.

38 XXV sammit ATJeS v Danange: vmeste k procvetaniju i garmonichnomu razvitiju [XXV APEC Summit in Da Nang: Together Towards Prosperity and Harmonious Development] (in Russ.). URL: http://kremlin.ru/events/president/news/56023/print, accessed on 23/10/2021. 
CPTPP is 5.74\%). ${ }^{39}$ Trade with the European Union is slightly higher $-36.8 \% .{ }^{40}$ This relative balance has been achieved literally over the past 3-5 years.

Secondly, a certain legal and regulatory framework for cooperation has already been developed. In 2015, the first free trade agreement between EAEU and Vietnam was signed. Despite the ambiguous trends in its implementation (exports during the period of its operation increased by only $9.9 \%$, and imports increased by $64.1 \%{ }^{41}$ ), it was the free trade zone with Vietnam that became a test of the pen in EAEU foreign trade policy and laid the foundation stone for the infrastructure of interaction between EAEU and APR. There is a non-preferential trade and economic agreement with the PRC. China is the largest trading partner of the EAEU among individual third countries, it accounts for more than $20 \%$ of the total foreign trade of the Union, and this figure is only growing.

The Agreement is the basis for the conjugation of the "One Belt, One Road" and Eurasian integration. As part of the implementation of the document, we are talking about a wide range of mutually interesting topics. For example, the issues of digital transport corridors are being worked out, which is aimed at improving container transit along with Western China - Western Europe route. Infrastructure is being developed to finance joint cooperation projects. That is, we are talking not only about trade but about full-scale economic cooperation. On 1 October 2019, a free trade agreement was concluded with Singapore. For it to come into effect, it is necessary to reach agreements on services and investments within the framework of bilateral negotiations of the EAEU countries with this partner. The EAEU does not yet have the relevant competence. A decision was made to negotiate a free trade agreement with India, and the feasibility of concluding a similar agreement with Indonesia is being studied. Close interaction has been established between the Eurasian Economic Commission and the ASEAN Secretariat in the format of a Memorandum, and a joint action plan until 2025 is being implemented.

The logic and analysis of the situation dictate several directions for further work. In our opinion, the priorities should be as follows.

\footnotetext{
39 Statistika vneshnej torgovli EAJeS [EAEU foreign trade statistics] (in Russ.). URL: http://www.eurasiancommission.org/ru/act/integr_i_makroec/dep_stat/tradestat/tables/extra/ Documents/2020_180/E202012_2_1.pdf, accessed on 23/10/2021.

40 Ibid.

41 EAJeS izuchit vozmozhnost' aktivizacii jeksporta v ramkah ZST s V'etnamom [The EAEU will explore the possibility of boosting exports under the FTA with Vietnam] (in Russ.). URL: https://eec.eaeunion.org/news/eaes-izuchit-vozmozhnost-aktivizatsii-eksporta-v-ramkah-zst-svetnamom, accessed on 23/10/2021.
} 
1. First, it is needed to calculate all the bottlenecks. For example, according to various estimates, in the event of a preferential EAEU-RCEP deal, a decline in output within the Union can be observed in such industries as mechanical engineering (vehicles and spare parts), light industry (textiles, clothing, leather goods), chemical industry (chemical, rubber and plastic products), food industry. ${ }^{42}$ This should be taken into account and play ahead of the curve.

2. Within the framework of the negotiations, it is extremely important to ensure the promotion of EAEU's own approaches in the field of customs-tariff and non-tariff regulation, as well as, which is especially important, in the field of technical regulation. That is, to prioritize those issues that have already been brought to the supranational level in the Union and on which positive practice has been developed. This will ensure the seamlessness of trade on principles that are understandable and comfortable for the business of the EAEU countries.

3. The EAEU international competence objectively needs adjustment. Consideration should be given to transferring competence in trade in services, as well as intellectual property and investment regime to the Union level. Changes must be made to Section IX of the Treaty on the EAEU. ${ }^{43}$ All key multilateral trade deals today include these positions in their outline. The interest of an external partner can diminish without the ability to discuss them. The Union should also be given more freedom in the course of international interaction. It is EAEU (in the person of the Eurasian Economic Commission $^{44}$ ) who should become the main negotiator, thereby implementing its assigned international legal personality.

\footnotetext{
${ }^{42}$ See, e.g.: Izotov, D. A.: Vlijanie torgovyh megaformatov v ATR na rossiǔskiǔ jeksport [The influence of trade mega-formats in the APR on Russian exports], Jekonomicheskie $i$ social'nye peremeny: fakty, tendencii, prognoz [Economic and social changes: facts, trends, forecast], 2021, 14(1), p. $41-55$ (in Russ.); Aliev, T. M., Baeva, M. A., Borgojakova, K. N. et al.: EAJeS i ASEAN: otkryvaja novye gorizonty sotrudnichestva: Analiticheskil doklad [EAEU and ASEAN: Opening New Horizons of Cooperation: Analytical Report], Moscow, VAVT, 2017 (in Russ.); Knobel', A. Ju., Sedalishhev, V. V.: Riski i vygody dlja EAJeS ot razlichnyh scenariev integracii $v$ Aziatsko-Tihookeanskom regione [Risks and benefits for the EAEU from various integration scenarios in the Asia-Pacific region.], Jekonomicheskaja politika [Economic policy.], 2017, 12(2), p. 72-85 (in Russ.).

43 Treaty on the Eurasian Economic Union. URL: https://www.un.org/en/ga/sixth/70/docs/ treaty_on_eeu.pdf, accessed on 21/10/2021.

44 On some points of the Commission's competence, see, e.g.: Entin, M., Galushko, D.: Interaction of the Eurasian Economic Union and its Member States in the sphere of Agriculture, Економика пољопривреде, 2021, vol. LXVIII, no. 2, pp. 491-501. doi:10.5937/ekoPolj2102491E
} 
4. To find the optimal format. The most promising is the comprehensive free trade agreement, in which the EAEU, RCEP, and CPTPP, that is, 19 countries, will become participants. This mitigates the risks that may arise when concluding bilateral preferential deals and maximizes the benefits. In this situation, the real GDP of Russia in the long term can grow from $0.74 \%$ to $1.32 \%$, and the GDP of Kazakhstan - from 0.92 to 1.72 percentage points. The effects for the Armenian, Belarusian, and Kyrgyz economies will also take place, but to a somewhat lesser extent. ${ }^{45}$

However, the given forecasts take into account only the benefits of zeroing tariffs and reducing non-tariff barriers. But the format we propose will make it possible to fully realize the transit potential of the Union, build up industrial cooperation, attract investment in infrastructure projects, and also stop subjective sanctions risks. At the same time, against the background of the emerging picture, Russia and the EAEU can become a kind of mediator in the growing economic interaction between EU and APR,${ }^{46}$ thereby creating conditions for restarting relations with the European Union. The horizons are much wider.

\section{CONCLUSION}

Implementation of such a global idea will not be quick. The necessary political conditions must mature. Specific messages have already been formulated at the highest level. Within the framework of the Supreme Eurasian Economic Council's meeting on 14 October 2021, its Chairman, President of Kazakhstan K.-Zh. K. Tokayev noted: «It would be interesting to work out approaches to interaction with a new trade association - the Regional Comprehensive Economic Partnership».

The work should get off the ground. The initiative in this matter can and should belong to the Eurasian Economic Commission. For example, we can talk about the creation of a dialogue format "EAEU-RCEP" within the framework of the current bilateral memorandum between the EEC and the ASEAN secretariat, which is also the depositary of the RCEP Agreement. It would be extremely important to launch such an initiative as part of one of the highest-level events in ASEAN or the EAEU as early as 2022. This will be an important step towards

\footnotetext{
45 See, e.g.: Monitoring aktual'nyh sobytij v oblasti mezhdunarodnoj torgovli № 29 ot 22 maja 2019 goda [Monitoring of current events in the field of international trade No. 29 dated May 22, 2019] (in Russ.). URL: https://www.vavt-imef.ru/analytics/monitoring/current-eventsin-the-field-of-international-trade-№29, accessed on 23/10/2021.

46 VRJeP: kljuchevaja veha v razvitii megaregionalizma [RCEP: a key milestone in the development of mega-regionalism] (in Russ.). URL: https://ru.valdaiclub.com/a/highlights/vrep-klyuchevaya-vekha-v-razvitii-megaregionalizma/?sphrase_id=418540, accessed on 23/10/2021.
} 
practical implementation of the idea of the Greater Eurasian Partnership - a unifying initiative open to all countries of Asia and Europe without exception.

\section{LITERATURE}

1. Aliev, T. M., Baeva, M. A., Borgojakova, K. N. et al.: EAJeS i ASEAN: otkryvaja novye gorizonty sotrudnichestva: Analiticheskiu doklad [EAEU and ASEAN: Opening New Horizons of Cooperation: Analytical Report], Moscow, VAVT, 2017.

2. Baklanov, P. Y., Romanov, M. T. Transboundary regions of East Asia: geographical and political preconditions and limitations to long-term development, GEOGRAPHY, ENVIRONMENT, SUSTAINABILITY, 2020, 13(1), pp. 57-63.

- DOI: https://doi.org/10.24057/2071-9388-2019-96.

3. Dowd, K.: A Trade Policy for a Brexited Britain, Institute of Economic Affairs Discussion Paper, 2017, 85, 2017. URL: https://ssrn.com/abstract=3853711, accessed on 23/10/2021.

4. Entin, M., Galushko, D.: Interaction of the Eurasian Economic Union and its Member States in the sphere of Agriculture, Ekonomika poljoprivrede, 2021, vol. LXVIII, no. 2, pp. 491-501.

- DOI: https://doi.org/10.5937/ekoPolj2102491E

5. Entin, M., Galushko, D. Resilience of the European Union as a determinant of its post-pandemic development (2021) Eastern Journal of European Studies, 12, pp. 212-230.

- DOI: https://doi.org/10.5937/ekoPolj2102491E

6. Flach, L., Hildenbrand, H., Teti, F.: The Regional Comprehensive Economic Partnership Agreement and Its Expected Effects on World Trade, Intereconomics, 2021, 56(2), p. 92-98.

- DOI: https://doi.org/10.1007/s10272-021-0960-2

7. Izotov, D. A.: Vlijanie torgovyh megaformatov v ATR na rossiǔskiǔ jeksport [The influence of trade mega-formats in the APR on Russian exports], Jekonomicheskie $i$ social'nye peremeny: fakty, tendencii, prognoz [Economic and social changes: facts, trends, forecast], 2021, 14(1), p. 41-55 (in Russ.).

8. Kawai, M., Wignaraja, G.: Asian FTAs: Trends, Prospects, and Challenges, Asian Development Bank Economics Working Paper Series, 2010, 226, p. 1.

- DOI: https://doi.org/10.2139/ssrn.1721911

9. Knobel', A. Ju., Sedalishhev, V. V.: Riski i vygody dlja EAJeS ot razlichnyh scenariev integracii v Aziatsko-Tihookeanskom regione [Risks and benefits for the EAEU from various integration scenarios in the Asia-Pacific region.], Jekonomicheskaja politika [Economic policy.], 2017, 12(2), p. 72-85.

- DOI: https://doi.org/10.18288/1994-5124-2017-2-03 
10. Quah, D.: The Global Economy's Shifting Centre of Gravity, Global Policy, 2011, 2(1), p. 3-9.

- DOI: https://doi.org/10.1111/j.1758-5899.2010.00066.x

11. Smith, H., Day, G., Thomas, B., Yeaman, L., The changing pattern of East Asia's growth, Economic Roundup, The Treasury, Australian Government, 2005, 1, pp. 45-67.

12. Woolcock, S.: The role of the European Union in the international trade and investment order, LSE Research Online Documents on Economics 102821, London School of Economics and Political Science, LSE Library, 2019.

13. Yates, R.: Understanding ASEAN's role in Asia-Pacific order. London, Palgrave Macmillan, 2019. (Critical Studies of the Asia-Pacific).

- DOI: https://doi.org/10.1007/978-3-030-12899-9 